\title{
Interactions of juvenile Lumbricus terrestris with adults and their burrow systems in a two-dimensional microcosm
}

\author{
Niki Grigoropoulou ${ }^{(1)}$, Kevin R. Butt(1) and Christopher N. Lowe(1)
}

\begin{abstract}
(1)University of Central Lancashire, School of Built and Natural Environment, Preston, PR1 2HE, United Kingdom. E-mail: ngrigoropoulou@uclan.ac.uk, krbutt@uclan.ac.uk, cnlowe@uclan.ac.uk
\end{abstract}

\begin{abstract}
The objective of this work was to evaluate interactions of Lumbricus terrestris juveniles with adults and with inherited burrow systems. An experiment was set up using a two dimensional Evans' boxes microcosm. Adult $L$. terrestris were added to 16 boxes (one individual per box) and kept in darkness at $17^{\circ} \mathrm{C}$ along with eight unoccupied boxes for two months. The adult $L$. terrestris were removed from eight randomly selected boxes, and $L$. terrestris juveniles were added (one juvenile per box), composing three treatments with eight replicates: 1, with an adult in an inherited burrow (ABJ); 2, alone in an inherited burrow (BJ); and 3, alone in a previously uninhabited box $(\mathrm{J})$. The proportion of juveniles occupying adult burrows observed was significantly different in treatments $\mathrm{ABJ}(48 \%)$ and $\mathrm{BJ}(75 \%)$. The mean mass of juveniles at experimental termination differed significantly among treatments and was greater in treatment $\mathrm{J}(4.04 \pm 0.39 \mathrm{~g})$ in comparison to the $\mathrm{BJ}(3.09 \pm 0.93 \mathrm{~g})$ and $\mathrm{ABJ}$ treatments $(2.13 \pm 0.64 \mathrm{~g})$. Results suggest a negative influence of both the presence of an adult and its burrow system on juvenile growth. Intraspecific competition partially explained this, but further investigation is required to examine how an inherited environment (i.e. burrow) could negatively affect the growth of juveniles.
\end{abstract}

Index terms: anecic, earthworm, intraspecific interactions.

\section{Interações de juvenis de Lumbricus terrestris com adultos e seus sistemas de galerias em um microcosmo bidimensional}

\begin{abstract}
Resumo - O objetivo deste trabalho foi avaliar as interações de juvenis de Lumbricus terrestris com indivíduos adultos e com sistemas de galerias herdados. $\mathrm{O}$ experimento foi realizado usando microcosmos bidimensionais de Evans como unidades experimentais. Adultos de L. terrestris foram colocados em 16 unidades experimentais (um indivíduo por unidade) e mantidos no escuro a $17^{\circ} \mathrm{C}$ juntamente com oito unidades experimentais inabitadas, por dois meses. Os adultos foram removidos de oito unidades selecionadas aleatoriamente e juvenis foram adicionados a todas as unidades experimentais (um indivíduo por unidade), em três tratamentos, com oito repetições: 1, com um adulto em um sistema de galerias herdado (ABJ); 2, sozinho em um sistema de galerias herdado (BJ); e 3, sozinho em uma unidade experimental inabitada (J). A proporção de juvenis observados ocupando as galerias feitas pelos adultos foi significativamente diferente nos tratamentos ABJ $(48 \%)$ e BJ (75\%). A biomassa média dos juvenis ao final do experimento diferiu significativamente entre os tratamentos e foi maior no tratamento J $(4.04 \pm 0.39 \mathrm{~g})$ em comparação com os tratamentos BJ $(3.09 \pm 0.93 \mathrm{~g})$ e ABJ $(2.13 \pm 0.64 \mathrm{~g})$. Os resultados sugerem uma influência negativa tanto da presença de um adulto quanto do seu sistema de galerias no crescimento dos juvenis. A competição intraespecífica explica parcialmente este fenômeno, porém novas investigações devem ser feitas para examinar como um ambiente herdado (galerias) pode afetar negativamente o crescimento de juvenis.
\end{abstract}

Termos para indexação: anécicas, minhocas, interações intraespecíficas.

\section{Introduction}

Biogenic constructions of Lumbricus terrestris (burrows and middens)modify the physical and chemical composition of soil and can therefore influence the abundance and distribution of other soil organisms (Jones et al., 1994). The vertical burrow of this species is a permanent structure used by the earthworm during its lifetime and potentially inherited by other individuals on death (Butt \& Nuutinen,
2005), as burrows may persist for decades (Shipitalo et al., 2004). Burrow walls are frequently lined with casts and mucus and surface organic material is transferred through the burrow system. Thus, a suitable environment is provided for growth of microfaunal and microfloral communities (Tiunov et al., 2001; Tiunov \& Dobrovolskaya, 2002). L. terrestris middens are above-ground accumulations of mixed organic 
material and soil, with an increased microbial activity (Schrader \& Seibel, 2001; Bohlen et al., 2002) which affects microarthropod communities (Eisenhauer et al., 2007) and fungal activity (Subler \& Kirsch, 1998). The increased abundance of microbes and microfauna renders litter in L. terrestris middens more palatable for soil organisms (including earthworms) than the surrounding material. In fact, the soil within and below middens has been found to sustain a greater number of epigeic and endogeic earthworms in addition to L. terrestris juveniles, compared with adjacent non-midden control samples (Butt \& Lowe, 2007).

Physical and chemical changes of soil in L. terrestris burrows and middens result from: 1, rearrangement of organic material across the soil profile; 2 , mixing of leaf litter with soil and its accumulation on the soil surface; 3, lining of burrows with mucus; and 4 , enhancement of the activity and number of microorganisms in burrows and middens. All of these factors could influence $L$. terrestris juveniles growth if they stay in close proximity to the parental burrow or midden soil. In previous work (Grigoropoulou et al., 2008), L. terrestris cocoons found in burrows were observed to be coated with fresh casting and the authors proposed that, besides functioning as a protective layer, these could also act as a potential food source for hatchlings on emergence. Moreover, possible regulation of temperature and moisture levels within the burrow could result in a more stable environment for hatchlings to grow (Butt \& Nuutinen, 2005). Finally, the large amount of energy expenditure for burrow construction by $L$. terrestris has been proposed as a possible cause for the L. terrestris burrow reuse by conspecifics observed in laboratory experiments (Butt et al., 2003; Grigoropoulou et al., 2008). It could therefore be argued that the burrow-midden complex of an adult $L$. terrestris is likely to have a positive impact on the growth and development of hatchling and juvenile $L$. terrestris.

Laboratory studies (Lowe \& Butt, 2002; Grigoropoulou et al., 2008) have shown that L.terrestris hatchlings will compete with adults for resources and space, and therefore would be expected to disperse before growing to a size where competitive interactions become intense.

Due to the little information available on intraspecific competition in L. terrestris, the objective of this work was to evaluate interactions of $L$. terrestris juveniles with adults and with inherited burrow systems.

\section{Materials and Methods}

In January 2007, an experiment was set up under controlled laboratory conditions. Glass-sided boxes $(0.2 \times 0.8 \times 0.008 \mathrm{~m})(\mathrm{n}=24)$ were constructed as described by Grigoropoulou et al. (2008) based on the design of Evans (1947), and were filled with moistened (25-30\%) sterilized soil (Boughton Loam \& Turf Management Ltd., UK), with leaf litter as food source. Leaves (Acer pseudoplatanus, Betula pubescens, Betula pendula, Fagus sylvatica, Quercus robur, Tilia cordata, Tilia platyphyllos) were obtained from a deciduous woodland in autumn and were air-dried for three days before being rewetted and surface-applied to the boxes, occupying the upper $0.05 \mathrm{~m}$. Large L. terrestris were collected from the same site and kept in darkness at $5^{\circ} \mathrm{C}$ in a $25 \mathrm{~L}$ container with soil and leaves for five days before use. Laboratory-grown L. terrestris hatchlings (mean mass of $0.07 \pm 0.02 \mathrm{~g}$ ) were kept in $600-\mathrm{mL}$ pots (one per pot) with moistened (30\%) sterilized soil and dried rewetted horse manure as food source, at a constant temperature of $17^{\circ} \mathrm{C}$, for 57 days until they reached a desired juvenile mass of $0.55 \pm 0.09 \mathrm{~g}$. This mass was chosen so that during the course of the experiment the earthworms would reach a size large enough to change burrowing behaviour, as observed by Lowe \& Butt (2002), and therefore exercise their potential interaction with adults.

Adult $(4.23 \pm 0.79 \mathrm{~g})$ L. terrestris were added to 16 boxes (one individual per box). These and the eight unoccupied boxes were kept in darkness at a constant temperature of $17^{\circ} \mathrm{C}$, with regular additions of water and leaves, for two months. Thereafter, the adult $L$. terrestris were removed from eight randomly selected boxes using a tungsten lamp as heat source, to drive the earthworm upwards, as described by Grigoropoulou et al. (2008). Juvenile L. terrestris previously maintained in culture were added to the experiment (one juvenile per box), which resulted in three treatments replicated eight times: juvenile $L$. terrestris in the presence of an adult in an inherited burrow system (ABJ); juvenile L terrestris only, in a fully constructed inherited burrow from which an adult had been removed (BJ); juvenile L. terrestris only, in the absence of both an adult and a burrow system, i.e. in a previously uninhabited box (J).

The boxes were maintained under the same conditions as pre-juvenile addition and monitored weekly over a 
three-month period. Burrowing activities of both adults and juveniles and their position within the burrow systems were recorded throughout the experiment. This was achieved by drawing the burrow architecture onto the surface of both glass plates of the Evans' box with a non-permanent marker pen. Photographs of the boxes with these drawings were then inserted into AutoCAD (Autodesk, 2008), where the burrow systems were plotted and their characteristics (i.e. depth and total length) were calculated. Three months after manipulation, the contents of the boxes were destructively sampled after the removal of one glass plate. Adults and juveniles were located, had their masses determined and their developmental stage recorded. L. terrestris burrow diameters were measured using internal callipers positioned at right angles to the burrow walls every $0.05 \mathrm{~m}$ along the total length of the burrows, within all boxes. Analysis of variance of the observed locations, the masses of all earthworms and the depth, length and diameter of the burrows was performed using Statistica (StatSoft Inc., USA).

\section{Results and Discussion}

At the experimentalmanipulation, all adult $L$.terrestris removed from the boxes $(\mathrm{n}=8)$ had a mean $( \pm \mathrm{SD})$ mass gain of $1.98 \pm 1.31 \mathrm{~g}$ and had developed burrows extending to a similar ( $p>0.05)$ mean depth of $0.73 \pm 0.01$ and $0.62 \pm 0.20 \mathrm{~m}$ in boxes of the ABJ and BJ treatments, respectively. The total length of the burrows constructed by adult $L$. terrestris at that time also did not significantly differ between $\mathrm{ABJ}$ and $\mathrm{BJ}$ treatments and had a mean of $2.83 \pm 0.66$ and $2.09 \pm 0.72 \mathrm{~m}$, respectively. In boxes of the ABJ treatment, the mean length of adult burrows had increased by a mean of $0.99 \pm 0.42 \mathrm{~m}$ (or $38 \pm 23 \%$ ) by the end of the three-month experimental period.

The depth of the burrows created by juvenile $L$. terrestris (treatment $\mathrm{J}$ ) developed at rates of $0.05 \pm 0.09,0.05 \pm 0.10$ and $0.03 \pm 0.08 \mathrm{~m}$ per week during the first, second and final month of the experiment respectively, extending to a mean depth of $0.56 \pm 0.19 \mathrm{~m}$. Under similar conditions (Grigoropoulou et al., 2008), adult $L$. terrestris were observed burrowing at doubled rate $(0.10 \mathrm{~m}$ per week) during the initial month of the experiment, reducing their rate of burrowing during the following month.

Evidence of the use of existing burrow systems by juvenile L. terrestris in the $\mathrm{ABJ}$ and $\mathrm{BJ}$ treatments included the significantly reduced burrowing activity of juveniles in those treatments when compared to treatment J. Moreover, regular observations of boxes revealed differences in juvenile position within existing burrows constructed by adults between the $\mathrm{ABJ}$ and BJ treatments. The total length of the burrows, measured at the end of the experiment, created by juvenile $L$. terrestris did not differ between the $\mathrm{ABJ}$ and BJ treatments and averaged at $0.31 \pm 0.21$ and $0.35 \pm 0.10 \mathrm{~m}$ respectively. However, the total burrow length of juveniles in treatment $\mathrm{J}$ was significantly greater when compared with that of both the $\mathrm{ABJ}$ and BJ treatments $(p<0.01)$, with a mean length of $1.82 \pm 0.27 \mathrm{~m}$. Also, in the $\mathrm{ABJ}$ treatment, the proportion of juvenile $L$. terrestris found to occupy existing adult burrows was of $47 \%$ (number of observations $=19$ ), which was not significantly different from 53\% (number of observations $=21$ ) of juveniles found to rest within their own created burrows. However, in the absence of an adult (BJ treatment) the proportion of juveniles making use of existing adult burrows was of $75 \%$ (number of observations $=49$ ) and significantly greater $(\mathrm{p}<0.01)$ than the $25 \%$ (number of observations $=16$ ) of juveniles found resting within the burrows they had created. The burrow diameter of adult and juvenile L. terrestris in treatment $\mathrm{ABJ}$ was significantly different $(p<0.01)$, with means of $9.86 \pm 2.01$ and $6.72 \pm 2.15 \mathrm{~mm}$ respectively, thus permitting differentiation of burrow systems. In other studies, adult $L$. terrestris were found to settle within existing burrows (Butt et al., 2003), without altering burrow shape (Grigoropoulou et al., 2008).

Adult $L$. terrestris were most frequently seen resting within their burrows at a depth of 0.20 to $0.25 \mathrm{~m}$ from the soil surface. Juveniles, however, were most frequently found within the leaf litter layer $(0-0.05 \mathrm{~m})$ across all three treatments. These results are similar to those obtained in previous experiments using Evans' boxes (Grigoropoulou et al., 2008). In a laboratory study using artificial soil cores, $L$. terrestris was observed to spend most time at a 0.02 to $0.10-\mathrm{m}$ distance from the soil surface (Bastardie et al., 2003). However, earthworms in this experiment were kept in an artificial environment and therefore the observed behaviours could be different from those under more natural conditions. Nevertheless, a preference for remaining close to the soil surface may be related to the favourable conditions within the burrow at these 
depths and to the close proximity of a food supply (i.e. the midden).

At the termination of the experiment, the mean mass of adult $L$. terrestris in boxes of the ABJ treatment was of $8.20 \pm 2.58 \mathrm{~g}$. All but one of the juveniles were found in boxes of this treatment, which resulted in a $88 \%$ survivorship. The survivorship of juveniles in the BJ and $\mathrm{J}$ treatments was of $100 \%$. The high survivorship, mass gain and extensive burrowing activity of earthworms suggest that the conditions in the Evans' boxes presented no problems for the maintenance of $L$. terrestris.

Mean $( \pm \mathrm{SE})$ mass of juveniles differed significantly across treatments $(p<0.05)$ and was greater in the $\mathrm{J}$ treatment $(4.05 \pm 0.14 \mathrm{~g})$, followed by the BJ $(3.09 \pm 0.33 \mathrm{~g})$ and $\mathrm{ABJ}$ treatments $(2.13 \pm 0.24 \mathrm{~g})$. Moreover, within the ABJ treatment, none of the juveniles had developed tubercula pubertatis (t.p.), a key structure found on the clitellum, by the end of the experiment. In boxes of the BJ treatment, $38 \%$ of the juveniles had developed t.p. and another $25 \%$ were mature (had a fully developed clitellum). The remaining $37 \%$ were still immature. Finally, in treatment $\mathrm{J}$ all $(100 \%)$ earthworms were clitellate.

Energy expenditure by earthworms in burrow construction would be expected to negatively affect their growth both in terms of mass gain and of developmental stage. In fact, $100 \%$ of the juveniles found in the $\mathrm{J}$ treatment had matured, while only $25 \%$ had matured in the BJ treatment. These results suggest that existing burrow systems created by adults and later used by juveniles do not directly benefit the earthworm and could even inhibit growth. The modification of the physical structure of soil by earthworms (Schrader et al., 2007) combined with changes in chemical composition of soil in burrows (Amador et al., 2006; Le Bayon \& Binet, 2006) and middens (Bohlen et al., 1997; Subler \& Kirsch, 1998) can affect diversity and activities of microfauna and microflora (Schrader \& Seibel, 2001; Tiunov et al., 2001; Tiunov \& Dobrovolskaya, 2002). All biological, chemical and physical changes in the L. terrestris burrow-midden complex may have an impact on juvenile growth. All juveniles found in boxes of the $\mathrm{ABJ}$ treatment were immature and had a significantly lower mass compared to juveniles in the BJ and $\mathrm{J}$ treatments. This result concurs with the results of other experiments (Lowe \& Butt, 2002; Grigoropoulou et al., 2008) and a possible explanation is intraspecific competition. Adults will compete with conspecifics for food resources and space and this competition will intensify with an increase in juvenile mass.

Further investigation is required to examine how an inherited environment (i.e. burrow) could negatively affect the growth of juveniles. Secretion of mucus by $L$. terrestris has been reported to function as an alarm pheromone for conspecifics only when induced by electric shock (Jiang et al., 1989). Such secretions are stable to light and heat, they can retain their activity for several months and are species-specific. They can be produced by earthworms under stressful environmental conditions or due to potential danger, and can cause conspecifics to disperse, hide, become immobilized, or induce physical signs of disturbance (Jiang et al., 1989). It is possible that the heat-induced removal of adult earthworms may have provoked the production of this type of secretion in the BJ boxes, which might account for reduced growth here. Alternatively, results obtained may be a function of the experimental method used to examine $L$. terrestris behaviour, i.e. a two-dimensional artificial environment within Evans' boxes. The presence of an existing burrow system might intuitively be thought of as an asset to a growing $L$. terrestris juvenile. Further experiments, both in the laboratory and potentially under field conditions, could usefully investigate whether mucus secretions in burrows could have a negative impact on both offspring and other conspecifics.

\section{Conclusions}

1. The reuse of Lumbricus terrestris burrows by conspecifics reduces burrowing activity, but does not directly benefit earthworm juveniles and can even inihibit growth and development.

2 . The presence of an adult $L$. terrestris in the burrow system further impairs growth and development of a juvenile.

\section{References}

AMADOR, J.A.; GORRES, J.H.; SAVIN, M.C. Effects of Lumbricus terrestris L. on nitrogen dynamics beyond the burrow. Applied Soil Ecology, v.33, 61-66, 2006.

AUTODESK. AutoCAD. San Rafael: Autodesk, 2008.

BASTARDIE,F.; CAPOWIEZ,Y.;CLUZEAU,D. Burrowing behaviour of radio-labelled earthworms revealed by analysis of 3D-trajectories in artificial soil cores. Pedobiologia, v.47, 554-559, 2003. 
BOHLEN, P.J.; EDWARDS, C.A.; ZHANG, Q.; PARMELEE, R.W.; ALLEN, M. Indirect effects of earthworms on microbial assimilation of labile carbon. Applied Soil Ecology, v.20, 255-261, 2002.

BOHLEN, P.J.; PARMELEE, R.W.; MCCARTNEY, D.A.; EDWARDS, C.A. Earthworm effects on carbon and nitrogen dynamics of surface litter in corn agroecosystems. Ecological Applications, v.7, 1341-1349, 1997.

BUTT, K.R.; LOWE, C.N. Presence of earthworm species within and beneath Lumbricus terrestris (L.) middens. European Journal of Soil Biology, v.43, 57-60, 2007.

BUTT, K.R.; NUUTINEN, V. The dawn of the dew worm. Biologist, v.52, 218-223, 2005.

BUTT, K.R.; NUUTINEN, V.; SIREN, T. Resource distribution and surface activity of adult Lumbricus terrestris L. in an experimental system. Pedobiologia, v.47, 548-553, 2003.

EISENHAUER, N.; PARTSCH, S.; PARKINSON, D.; SCHEU, $\mathrm{S}$. Invasion of a deciduous forest by earthworms: changes in soil chemistry, microflora, microarthropods and vegetation. Soil Biology \& Biochemistry, v.39, 1099-1110, 2007.

EVANS, A.C. Method of studying the burrowing activity of earthworms. Annals and Magazine of Natural History, v.11, 643-650, 1947.

GRIGOROPOULOU, N.; BUTT, K.R.; LOWE, C.N. Effects of adult Lumbricus terrestris on cocoons and hatchlings in Evans' boxes. Pedobiologia, v.51, 343-349, 2008.

JIANG, X.C.; WANG, D.; HALPERN, M. Isolation and characterization of alarm pheromone from electric shock-induced earthworm secretion. Pharmacology Biochemistry and Behavior, v.34, 213-221, 1989.
JONES, C.G.; LAWTON, J.H.; SHACHAK, M. Organisms as ecosystem engineers. Oikos, v.69, 373-386, 1994.

LE BAYON, R.C.; BINET, F. Earthworms change the distribution and availability of phosphorous in organic substrates. Soil Biology and Biochemistry, v.38, 235-246, 2006.

LOWE, C.N.; BUTT, K.R. Growth of hatchling earthworms in the presence of adults: interactions in laboratory culture. Biology and Fertility of Soils, v.35, p.204-209, 2002.

SCHRADER, S.; ROGASIK, H.; ONASCH, I.; JEGOU, D. Assessment of soil structural differentiation around earthworm burrows by means of X-ray computed tomography and scanning electron microscopy. Geoderma, v.137, 378-387, 2007.

SCHRADER, S.; SEIBEL, C. Impact of cultivation management in an agroecosystem on hot spot effects of earthworm middens. European Journal of Soil Biology, v.37, 309-313, 2001.

SHIPITALO, M.J.; NUUTINEN, V.; BUTT, K.R. Interaction of earthworm burrows and cracks in a clayey, subsurface-drained, soil. Applied Soil Ecology, v.26, 209-217, 2004.

SUBLER, S.; KIRSCH, A.S. Spring dynamics of soil carbon, nitrogen, and microbial activity in earthworm middens in a no-till cornfield. Biology and Fertility of Soils, v.26, 243-249, 1998.

TIUNOV, A.V.; BONKOWSKI, M.; ALPHEI, J.; SCHEU, S. Microflora, Protozoa and Nematoda in Lumbricus terrestris burrow walls: a laboratory experiment. Pedobiologia, v.45, 46-60, 2001.

TIUNOV, A.V.; DOBROVOLSKAYA, T.G. Fungal and bacterial communities in Lumbricus terrestris burrow walls: a laboratory experiment. Pedobiologia, v.46, 595-605, 2002.

Received on September 12, 2008 and accepted on June 29, 2009 